\title{
EFFECT OF PLANT ANATOMY ON DETERMINATION OF IRRIGATION STRATEGY UNDER THE ECOLOGICAL CONDITIONS OF SOILLESS AGRICULTURE
}

\author{
TUYLU, G. İ. ${ }^{*}-$ TUYLU, M. ${ }^{2}$ \\ ${ }^{I}$ Department of Agricultural Structures and Irrigation, Faculty of Agriculture, University of \\ Harran, Şanlıurfa, Turkey \\ ${ }^{2}$ Graduated from Department of Biology, Institute of Science, University of Süleyman Demirel, \\ Isparta, Turkey \\ *Corresponding author \\ e-mail: gokhantuylu@harran.edu.tr \\ (Received $25^{\text {th }}$ May 2019; accepted $9^{\text {th }}$ Sep 2019)
}

\begin{abstract}
In the study, it was aimed to determine the optimum irrigation issue by examining the anatomical features of Lycopersicon esculentum Mill. cv. Ceren cultivated in perlite by different irrigation treatments. Irrigation strategies were created based on the amount of drainage water and different irrigation applications were performed by using the drip irrigation system. For anatomical examination, cross sections were taken from the samples of the root, stem and leaf by microtome and examined by light microscopy. Some tissues in the root, stem, and leaf under over-irrigation and limited irrigation conditions changed significantly. As a result, the condition created by reducing $25 \%$ of irrigation water was determined as the optimum irrigation issue in four different irrigation applications. The amount of drainage under optimum condition was $10 \%$ of the amount of irrigation water applied. The study will contribute to the researchers to optimize the ecological condition in terms of irrigation in greenhouse.
\end{abstract}

Keywords: costs, plant histology, stress, tomato, water management

\section{Introduction}

Soil and freshwater resources are within the guarantee of economic and social order in society. Limited land and freshwater resources in the world and in Turkey have been freely used by mankind for many years without any problems. However, later it was negatively affected by climate change and abuse of agricultural land. On the other hand, requirement for the crop product increased due to rapid increase of population. Greenhouse improvement has been developed in order to reduce or eliminate these negative effects (Tuylu et al., 2018).

Today vegetable production in Turkey is $28.410^{6}$ ton and ranks $4^{\text {th }}$ in the world (Yanmaz et al., 2015). Approximately $87 \%$ of vegetable production is open and $13 \%$ is under cover $(61,000 \mathrm{ha})$. Tomato which is one of the vegetables cultivated in Turkey ranks $1^{\text {st }}$ with the amount of $11.810^{6}$ ton (Anonymous, 2015).

Today soil and soilless agriculture can be performed depending on the irrigation and crop production technologies developed in the greenhouse. Soilless agriculture is more productive than soil agriculture and its production cost is half of soil agriculture (Özkan, 2014). On the other hand, as a result of using geothermal water resources to heat greenhouse, the concept of geothermal greenhouse has started to develop in Turkey and greenhouse areas have increased where geothermal resources are available. Karaali, Şanlıurfa is a province where geothermal water is used for greenhouse heating and plant 
production is performed by using high technology in modern greenhouse (Deliboran et al., 2013).

In the studies carried out in plant cultivation in greenhouses, $30-35 \%$ free drainage condition has been commonly used for the irrigation applications mentioned in Winsor and Shwarz (1990), Lieth (1996), and Öztekin et al. (2017). Irrigation applications are effective on anatomical, morphological, physiological, etc. features of plants. Plants try to survive by developing many reversible or irreversible responses to all biotic or abiotic environmental factors they perceive as stress effect (Korkmaz and Durmaz, 2017).

In this way the plants become compatible with the factors of their habitat by developing stress responses. The responses developed by the plants to adapt to stress conditions can be due to changes in physiological, morphological, anatomical, etc. features. In cultivation, irrigation is one of the important abiotic factor for creation of ecological request of plants. If the accurate irrigation strategy can not be determined, water stress or drought stress condition occurs when over-irrigation or limited irrigation is applied. It causes anatomical changes in the plant. The changes can occur in various tissues. For this reason, it was aimed to determine the optimum irrigation issue for the variety studied by examining anatomical features of the plants cultivated by applying different irrigation issues. The study will contribute to the producers to determine accurate irrigation strategy in greenhouse and also support the researchers for literature to optimize the ecological condition in terms of irrigation in greenhouse in the World.

\section{Materials and methods}

The workout was carried out in polycarbonate covered greenhouse in Harran University, Şanlıurfa, Turkey during the spring of 2016. Tomato (Lycopersicon esculentum Mill. cv. Ceren) was cultivated in perlite by using drip irrigation system (Fig. 1). Anatomical studies were performed in the laboratories at the Department of Biology in Ankara University, Ankara, Turkey.

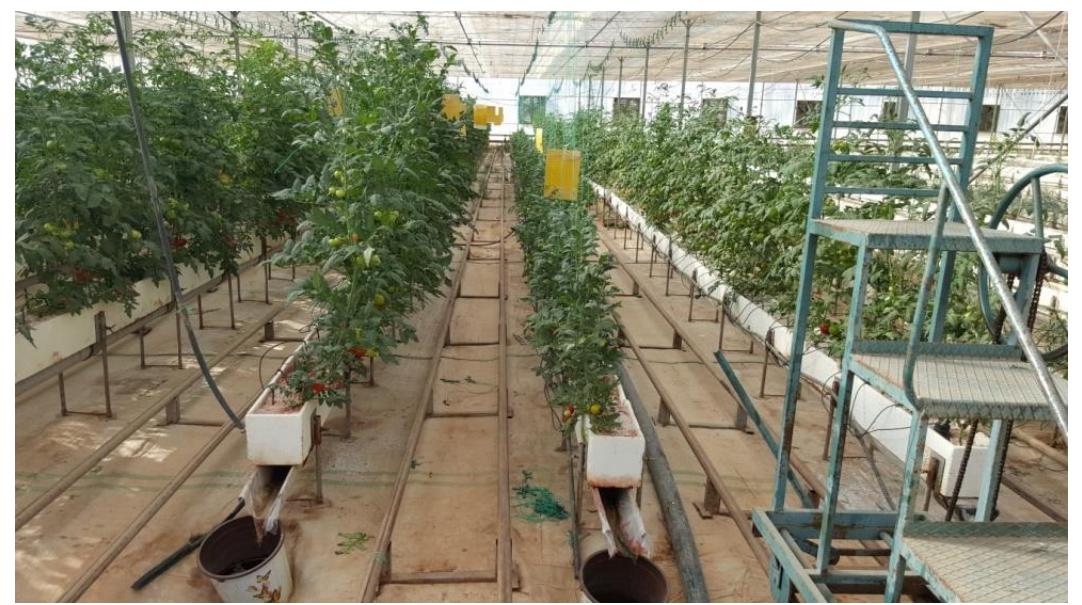

Figure 1. An appearance of cultivation area in the greenhouse

Şanliurfa is situated in the south eastern Anatolia, Turkey. The workout area is 465 above sea level and located between $37^{\circ} 08^{\prime} \mathrm{N}$ latitude and $38^{\circ} 46^{\prime} \mathrm{E}$ longitude (Demirok and Tuylu, 2017). 
Şanliurfa has a climate feature that is hot and dry in summers and warm in winters. Some climate values measured in and outside the greenhouse for the year 2016 when the workout was carried out are presented in Tables 1 and 2, respectively.

Table 1. Some climate parameters measured in greenhouse in 2016

\begin{tabular}{c|c|c|c}
\hline Months & Decades & Temperature $^{*}\left({ }^{\circ} \mathbf{C}\right)$ & Relative humidity $^{*}(\boldsymbol{\%})$ \\
\hline \multirow{2}{*}{ April } & 2 & 23.4 & 30.6 \\
& 3 & 24.3 & 28.0 \\
\hline \multirow{3}{*}{ May } & 1 & 23.8 & 33.1 \\
& 2 & 27.9 & 30.0 \\
& 3 & 26.1 & 31.6 \\
\hline \multirow{3}{*}{ June } & 1 & 29.9 & 28.7 \\
& 2 & 31.0 & 26.8 \\
& 3 & 35.3 & 28.3 \\
\hline \multirow{3}{*}{ July } & 1 & 35.4 & 27.1 \\
& 2 & 35.8 & 28.7 \\
& 3 & 35.4 & 28.3 \\
\hline
\end{tabular}

*Measured at 14:00 pm

Table 2. Average climate values of 2016 and 1985-2016 long years (LY) in research area (Anonymous, 2016)

\begin{tabular}{|c|c|c|c|c|c|c|c|}
\hline \multicolumn{2}{|c|}{$\begin{array}{c}\text { Climate } \\
\text { parameters }\end{array}$} & \multirow{2}{*}{$\begin{array}{c}\text { Max. } \\
\text { temperature } \\
\left({ }^{\circ} \mathbf{C}\right)\end{array}$} & \multirow{2}{*}{$\begin{array}{c}\text { Min. } \\
\text { temperature } \\
\left({ }^{\circ} \mathbf{C}\right)\end{array}$} & \multirow{2}{*}{$\begin{array}{c}\text { Ort. } \\
\text { Temperature } \\
\left({ }^{\circ} \mathbf{C}\right)\end{array}$} & \multirow{2}{*}{$\begin{array}{c}\text { Relative } \\
\text { humidity } \\
(\%)\end{array}$} & \multirow{2}{*}{$\begin{array}{c}\text { Wind } \\
\text { speed } \\
\left(2 \mathrm{~m} \mathrm{~s}^{-1}\right)\end{array}$} & \multirow{2}{*}{$\begin{array}{l}\text { Hours of } \\
\text { sunshine (h) }\end{array}$} \\
\hline Months & Year & & & & & & \\
\hline \multirow{2}{*}{ April } & 2016 & 32.7 & 7.4 & 20.6 & 36.1 & 1.4 & 8.90 \\
\hline & LY & 22.5 & 10.8 & 16.2 & 53.4 & 1.5 & 7.55 \\
\hline \multirow{2}{*}{ May } & 2016 & 35.0 & 10.7 & 23.2 & 38.3 & 1.9 & 10.20 \\
\hline & LY & 29.7 & 19.7 & 21.9 & 39.4 & 1.7 & 9.70 \\
\hline \multirow{2}{*}{ June } & 2016 & 42.0 & 18.9 & 29.8 & 28.0 & 1.9 & 11.90 \\
\hline & LY & 34.9 & 21.0 & 28.3 & 35.2 & 2.0 & 11.95 \\
\hline \multirow{2}{*}{ July } & 2016 & 43.0 & 20.9 & 33.0 & 25.4 & 1.9 & 12.40 \\
\hline & LY & 37.4 & 25.7 & 33.4 & 29.1 & 1.9 & 12.00 \\
\hline
\end{tabular}

The workout was created as with 3 replications according to the random parcels plant pattern. 8 plants were cultivated in each pot. 2 of 8 plants cultivated were separated as edge effect. The samples were randomly taken from the remaining 6 plants and were examined.

Perlite cultivation condition was created by filling perlite in white styrofoam pots with sizes of $100 \times 20 \times 20 \mathrm{~cm}$ and drainage holes at the bottom. The seedlings were planted as $135 \times 25 \mathrm{~cm}$ or more row spacing $\left(2.9\right.$ plants $\left.\mathrm{m}^{-2}\right)$ (Fig. 1). The nutrient solution used were passed through the filter and water meter by taking from the 1 tonreservoir with centrifugal pump and was given to the plants by means of four-outlet drip irrigation system set up on pressure-regulated dripper in the $8 \mathrm{~L} \mathrm{~h}^{-1}$ flow on lateral pipe 
(Ø16). The workout design was performed according to the open feed system and the nutrient solution that was drained was not used again.

In the study, the irrigation issues were planned according to free drainage condition (Winsor and Shwarz, 1990; Lieth, 1996; Öztekin et al., 2017). The issues were created according to four different irrigation levels which were $\mathrm{I}_{1}, \mathrm{I}_{2}, \mathrm{I}_{3}$, and $\mathrm{I}_{4}$. $\mathrm{I}_{1}$ was the issue allowed $20 \%$ drainage of irrigation water. $\mathrm{I}_{2}, \mathrm{I}_{3}$, and $\mathrm{I}_{4}$ were planned by proportionally reducing the amount of irrigation water used in $\mathrm{I}_{1}$ issue $(25,50,75 \%$, respectively).

Nutrient solution was modified by using Arnon and Hogland (Tuylu et al., 2018). Stock A and Stock B solutions were separately prepared (Table 3). Electrical conductivity (EC) of nutrient solution was measured as $2.5 \mathrm{dS} \mathrm{m}^{-1}$ by EC meter and $\mathrm{pH}$ of nutrient solution was fixed at 5.8-6.5 by using nitric acid. In soilless agriculture EC of nutrient solution has to be kept at optimum level. While high electrical conductivity (EC) reduces the yield affecting number of fruit, the diameter of fruit and the thickness of pericarp negatively, it causes increase of parameters of quality such as titratable acidity and the amount of dry substance which is easily soluble in water reducing glucose and lycopene (Söylemez and Pakyürek, 2017).

Table 3. The content of element in nutrient solution $\left(\mathrm{mg} l^{-1}\right)$

\begin{tabular}{c|c|c|c|c|c|c|c|c|c|c|c}
\hline \multicolumn{1}{c|}{ Stock A } & \multicolumn{3}{c}{ Stock B } \\
\hline $\mathrm{N}$ & $\mathrm{P}$ & $\mathrm{K}$ & $\mathrm{S}$ & $\mathrm{Mg}$ & $\mathrm{Mn}$ & $\mathrm{B}$ & $\mathrm{Cu}$ & $\mathrm{Zn}$ & $\mathrm{Mo}$ & $\mathrm{Ca}$ & $\mathrm{Fe}$ \\
\hline 210 & 31 & 234 & 64 & 48 & 0.5 & 0.5 & 0.02 & 0.05 & 0.01 & 200 & 2.8 \\
\hline
\end{tabular}

The samples of plants vegetatively and generatively grown were kept in alcohol $70 \%$ for anatomical studies (Figs. 2 and 3). Dehydration was applied to small pieces taken from the lower, middle, and upper parts of the root, stem and, leaf by means of different ethyl alcohol series. Then, they were saturated with paraffin. The samples were embedded in paraffin blocks to take cross sections. 8-10 $\mu \mathrm{m}$ thick cross sections from the root and the leaf and 20-30 $\mu \mathrm{m}$ thick cross sections from the stem were taken by microtome Leica SM 2000 R. The cross sections were stained by safranin-fast green (Tuylu et al., 2017; Tuylu, 2018a). They were examined by light microscope Leica 1000 and the results were photographed by digital camera Leica EC3.
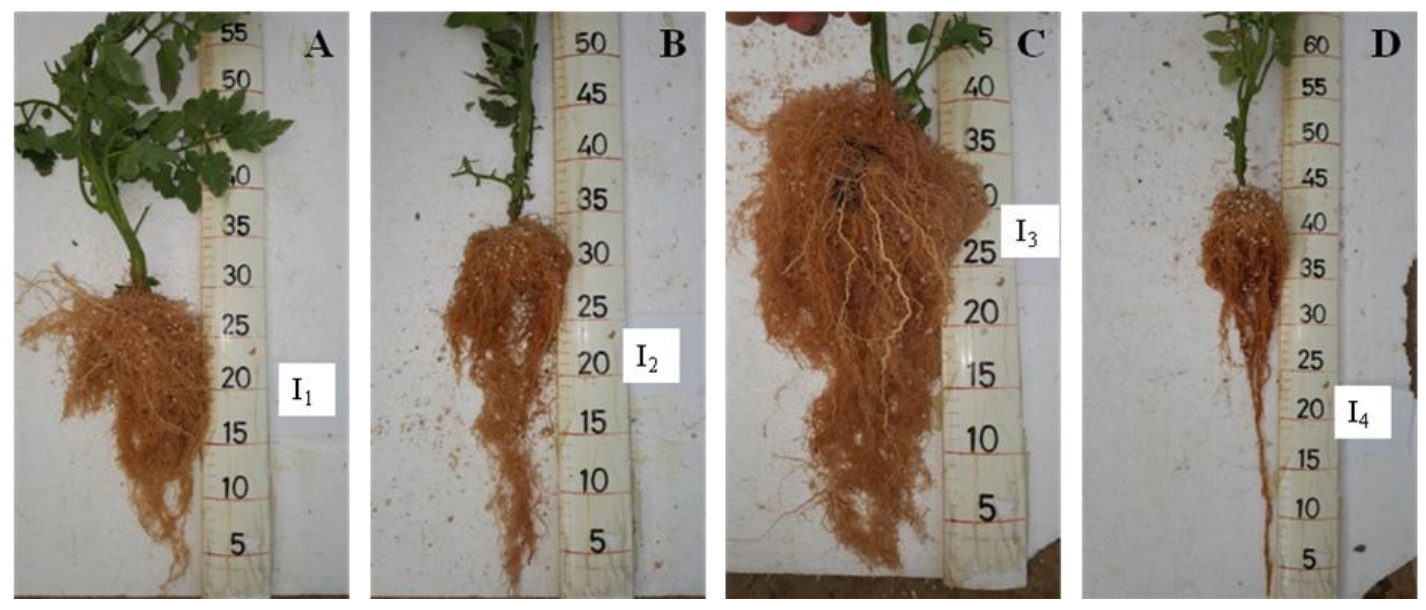

Figure 2. Morphological appearance of the roots grown in different irrigation areas. $A: I_{1}, B$ : $I_{2}, C: I_{3}, D: I_{4}$ 

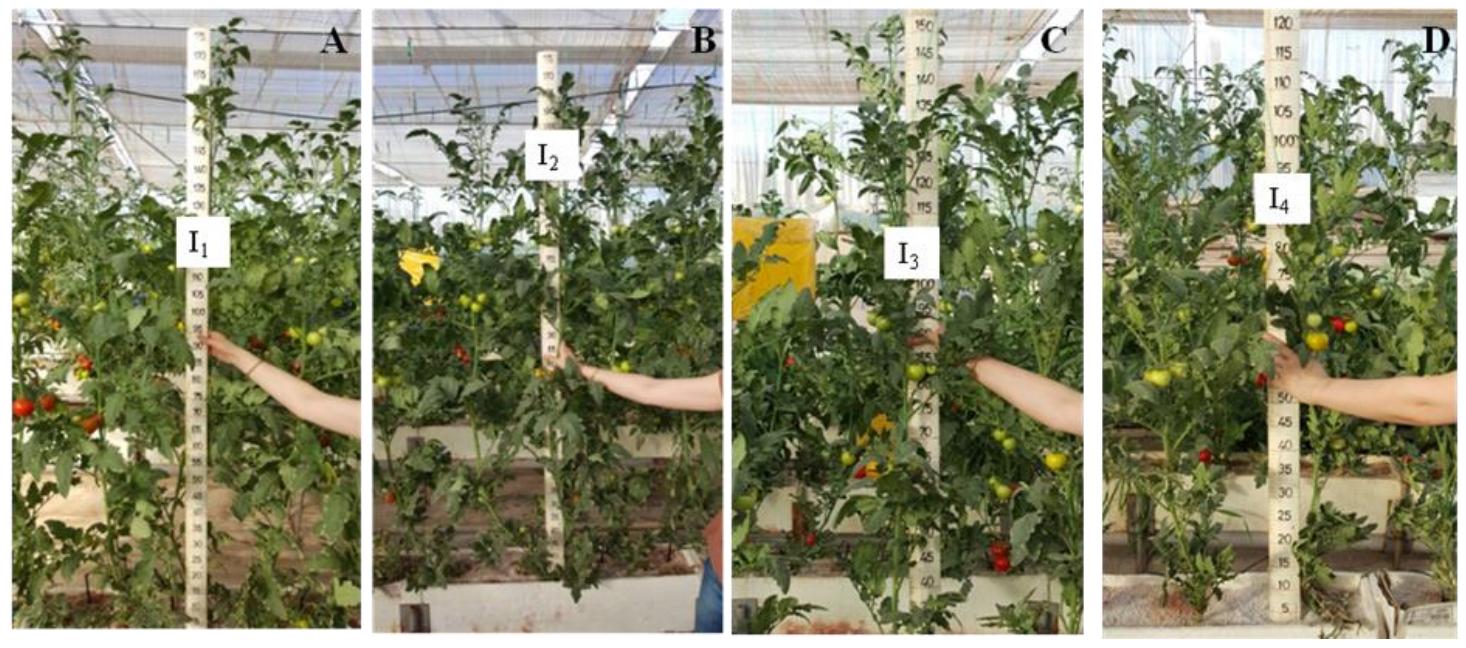

Figure 3. Morphological appearance of the stems and leaves grown in different irrigation areas. $A: I_{1}, B: I_{2}, C: I_{3}, D: I_{4}$

The photos are completely original. Biometric measurements were performed in some tissues by using Las v4.3 program. 3 groups in itself for each replication were created in the workout. The total number of cross sections taken from the plants and examined is 90 on 9 preparats for each replication and total 270 values of measurement were obtained by taking 3 from each section. The arithmetic mean of the values of measurements and mean standard error were calculated by using Microsoft Excel computer software and the results were anatomically expressed.

\section{Results}

Results for some anatomical features of the root, stem and leaf under different irrigation applications

\section{Roots}

The roots under all the conditions were formed by the cortex composed of wavywalled cells surrounded by one-layered epidermis, one-layered endodermis, and onelayered pericycle. Prismatic crystals were observed (Fig. 4). Endodermis and pericycle were seen in some sections under $\mathrm{I}_{2}$ and $\mathrm{I}_{4}$ (Figs. 5 and 6 ). Both prismatic crystals and druz crystals were also seen under $\mathrm{I}_{2}$. Prismatic crystals were regularly observed in parenchymatic cells around endodermis under $\mathrm{I}_{3}$ (Fig. 7). Parenchymatic cells like a large air space in cortex were seen in some sections under $\mathrm{I}_{4}$.

According to the biometric measurements performed in some tissues of the roots under four conditions; the thickness of cortex under $\mathrm{I}_{3}$ and $\mathrm{I}_{4}$ increased more than the one under $\mathrm{I}_{2}(p<0.01 ; p<0.05$; respectively). There was no significant change in the thickness of cortex under $\mathrm{I}_{1}(p>0.05)$. The diameter of xylem vessels narrowed under $\mathrm{I}_{1}, \mathrm{I}_{3}$, and $\mathrm{I}_{4}\left(p<0.05 ; p<0.01 ; p<0.01\right.$, respectively) more than the one under $\mathrm{I}_{2}$ (Fig. 8). According to the results of the biometric measurements, the roots under the other issues underwent anatomical changes comparing to the ones under $I_{2}$ statistically and the $\mathrm{I}_{2}$ condition was determined as optimum issue $(p<0.01$ : highly significant, $p<0.05$ : significant, $p>0.05$ : no significant). 

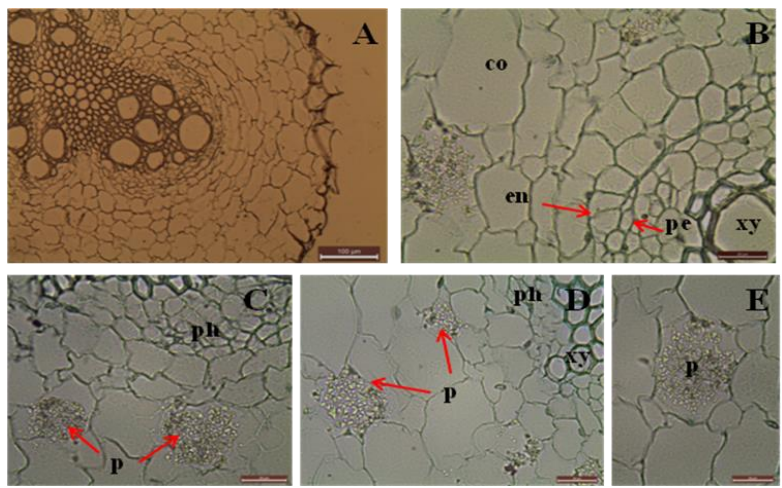

Figure 4. The anatomy of the root cultivated under $I_{1}$ (cross section). A: general shape of root, bar $=100 \mu \mathrm{m}, \mathrm{B}$ : cortex (co), endodermis (en), pericycle (pe), xylem (xy), bar $=20 \mu \mathrm{m}, C$ : phloem (ph), prismatic crystal (p), bar $=20 \mu \mathrm{m}, \mathrm{D}$ : phloem (ph), xylem (xy), prismatic crystal (p), bar $=20 \mu \mathrm{m}$, E: prismatic crystal (p), bar $=20 \mu \mathrm{m}$
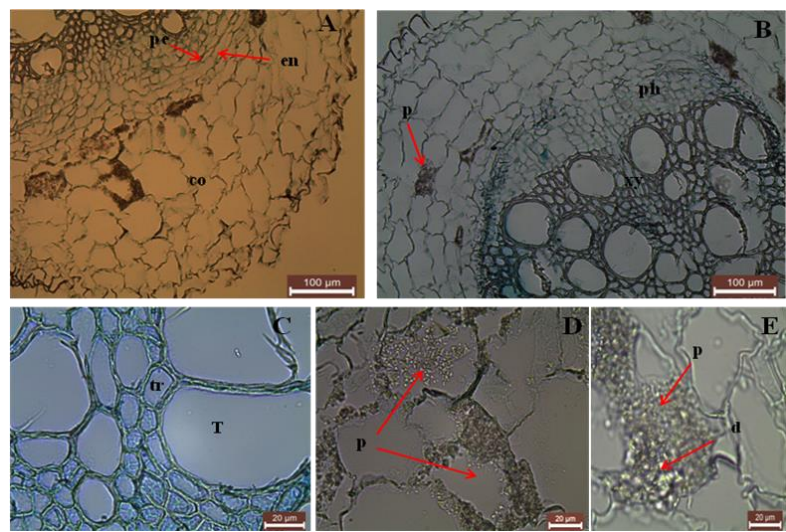

Figure 5. The anatomy of the root cultivated under $I_{2}$ (cross section). A: cortex (co), endodermis (en), pericycle (pe), bar $=100 \mu \mathrm{m}, \mathrm{B}:$ phloem (ph), xylem (xy), prismatic crystal

$(p)$, bar $=100 \mu \mathrm{m}, C$ : trachea $(T)$, tracheid $(\mathrm{tr})$, bar $=20 \mu \mathrm{m}$, D: prismatic crystal $(p)$, bar $=20 \mu \mathrm{m}$, E: prismatic crystal (p), druz crystal (d), bar $=20 \mu \mathrm{m}$
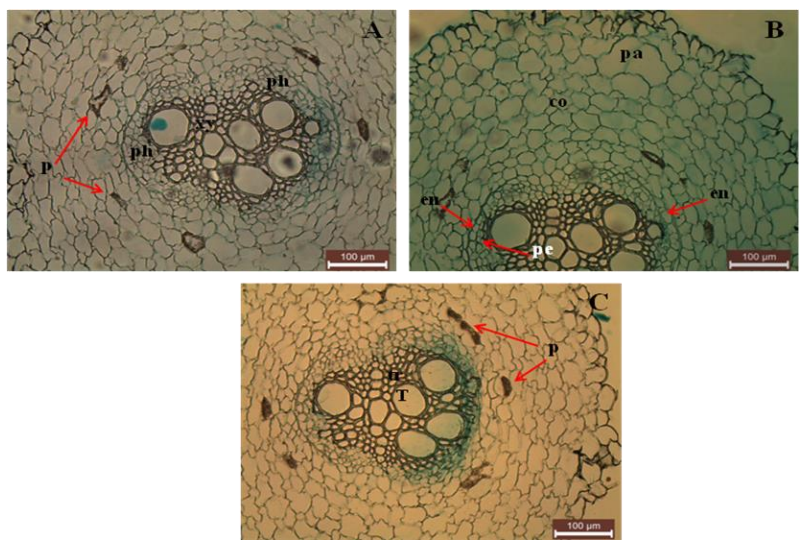

Figure 6. The anatomy of the root cultivated under $I_{4}$ (cross section). A: phloem (ph), xylem $(x y)$, prismatic crystal ( $p)$, bar $=100 \mu \mathrm{m}, \mathrm{B}$ : cortex (co), parenchymatic cell (pa), endodermis (en), pericycle (pe), bar $=100 \mu \mathrm{m}, \mathrm{C}$ : trachea (T), tracheid (tr), prismatic crystal $(p)$, bar $=100 \mu \mathrm{m}$ 


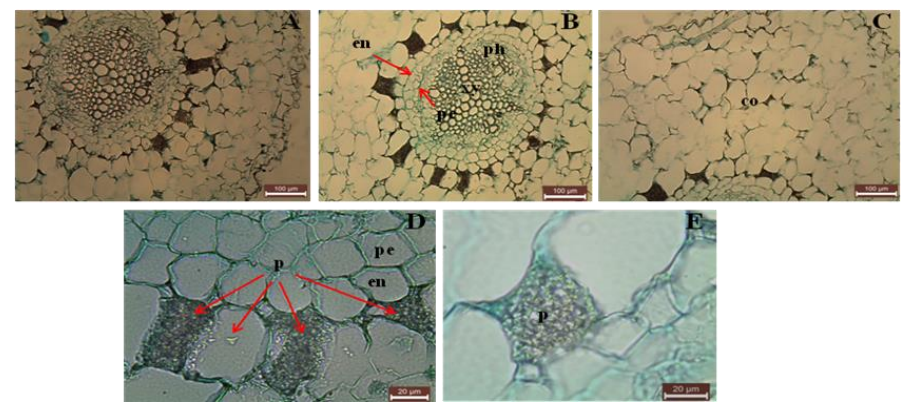

Figure 7. The anatomy of the root cultivated under $I_{3}$ (cross section). A: general shape of root, bar $=100 \mu \mathrm{m}, \mathrm{B}:$ endodermis (en), pericycle (pe), phloem (ph), xylem (xy), bar = $100 \mu \mathrm{m}, \mathrm{C}$ : cortex (co), bar $=100 \mu \mathrm{m}, \mathrm{D}$ : endodermis (en), pericycle (pe), prismatic crystal ( $p)$,

bar $=20 \mu \mathrm{m}$, E: prismatic crystal (p), bar $=20 \mu \mathrm{m}$
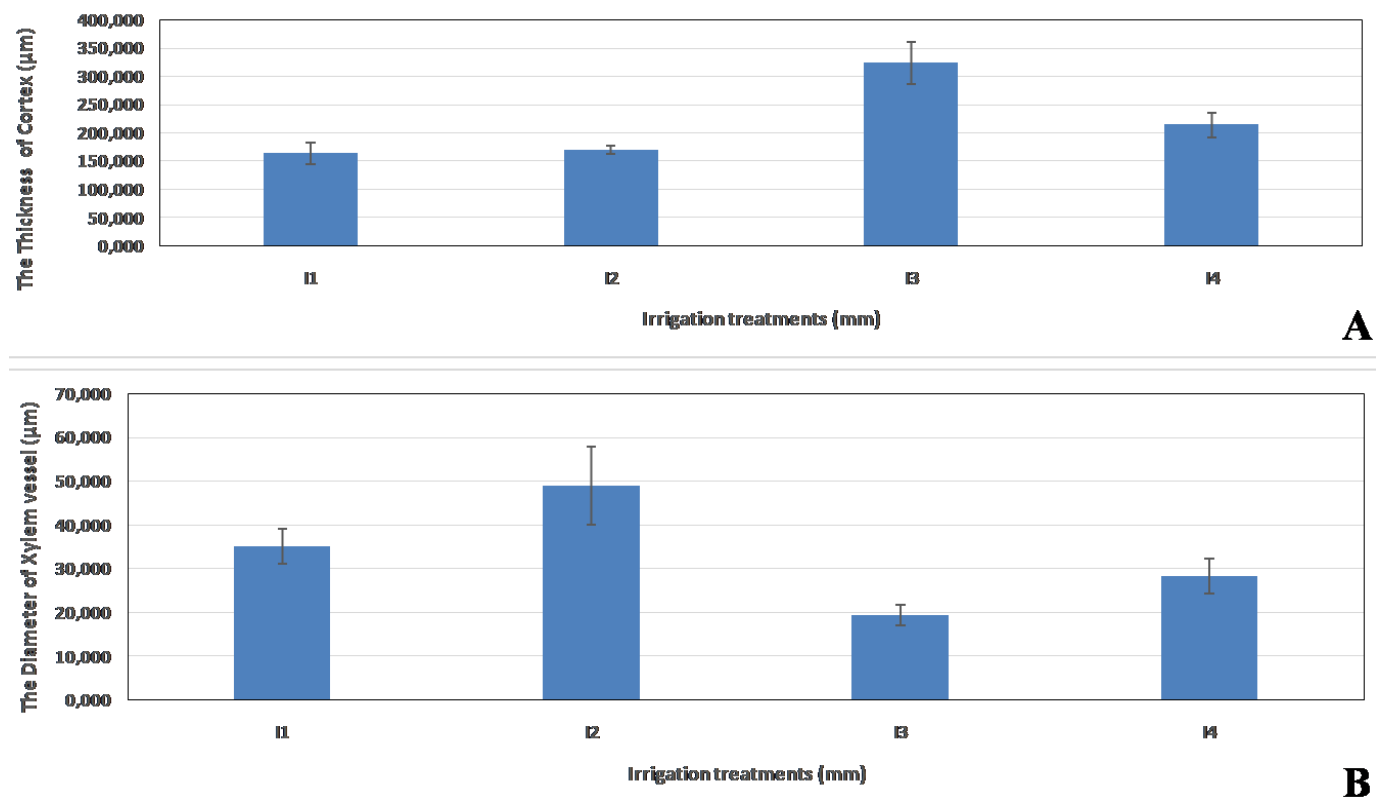

Figure 8. Measurements of some tissues in roots of Ceren cv. under different irrigation treatment conditions. A. The relationship between irrigation treatments and thickness of cortex.

$B$. The relationship between irrigation treatments and diameter of xylem vessel

\section{Stems}

The stems under all the conditions were formed by one- layered epidermis, 1-2 layered chlorenchyma with large spaces between the cells, 4-5 layered collenchyma, 4-5 or 5-6 layered cortex. The pith was parenchymatic surrounded by bicollateral vascular bundles. 3-4 layered cambium and seconder xylem rays under $\mathrm{I}_{1}$ and $\mathrm{I}_{3}$ were observed (Figs. 9 and 11). The cambium was 4-5 layered under $\mathrm{I}_{4}$ (Fig. 12). Sclerenchyma cells supported vascular bundles on both sides around phloems. All the stems had stomata, epidermal and glandular hairs. While prismatic crystals were generally observed, druz crystals were seen among prismatic crystals in some sections. Prismatic crystals in chlorenchyma under $\mathrm{I}_{2}$, air spaces in chlorenchyma in some sections under $\mathrm{I}_{4}$ and starch molecules under $\mathrm{I}_{2}, \mathrm{I}_{3}$, and $\mathrm{I}_{4}$ were observed (Figs. 10, 11 and 12). Starch molecules were rarely seen under $\mathrm{I}_{1}$. 
According to the biometric measurements performed in some tissues of the stems under four conditions, cuticle thickened under $\mathrm{I}_{1}$ and $\mathrm{I}_{4}(p<0.01 ; p<0.05$, respectively). It was not affected clearly under $\mathrm{I}_{3}(p>0.05)$. Epidermis did not change clearly under $\mathrm{I}_{1}$ $(p>0.05)$, but it significantly thickened under $\mathrm{I}_{3}$ and $\mathrm{I}_{4}(p<0.05)$. Cortex did not change clearly under $\mathrm{I}_{1}$ and $\mathrm{I}_{3}(p>0.05)$, but it significantly thickened under $\mathrm{I}_{4}(p<0.05)$. Xylem vessel narrowed under $\mathrm{I}_{1}, \mathrm{I}_{3}$, and $\mathrm{I}_{4}$ comparing to $\mathrm{I}_{2}(p<0.05 ; p<0.05 ; p<0.01$, respectively) (Fig. 13). According to the results of the biometric measurements, the stems under the other issues underwent anatomical changes comparing to the ones under $\mathrm{I}_{2}$ statistically and the $\mathrm{I}_{2}$ condition was determined as optimum issue.

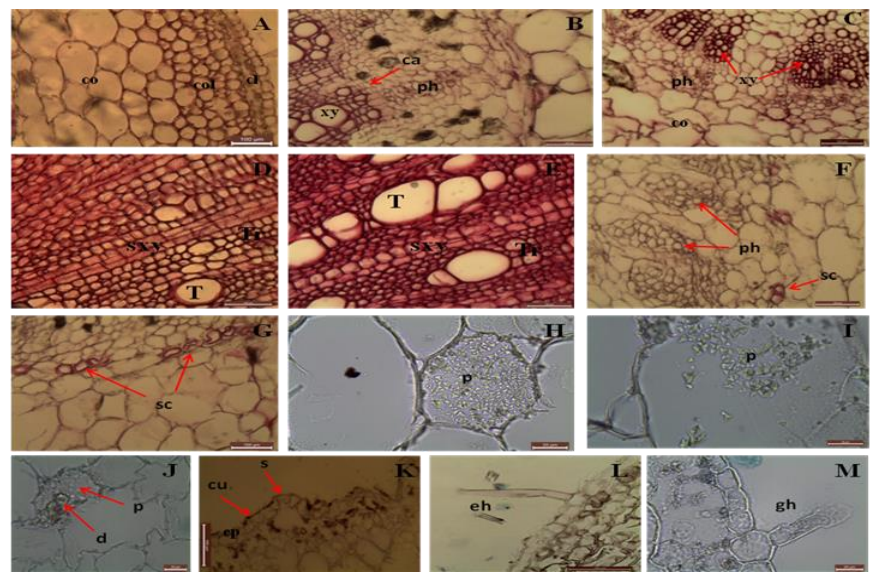

Figure 9. The anatomy of the stem cultivated $I_{l}$ (cross section). A: chlorenchyma (cl), collenchyma (col), cortex (co), bar $=100 \mu \mathrm{m}, \mathrm{B}:$ phloem (ph), xylem (xy), cambium (ca), bar $=100 \mu \mathrm{m}, C$ : cortex (co), phloem (ph), xylem (xy), bar = $100 \mu \mathrm{m}, \mathrm{D}$ : trachea $(T)$, tracheid (tr), seconder xylem (sxy) bar $=100 \mu \mathrm{m}, \mathrm{E}$ : trachea (T), tracheid (tr), seconder xylem (sxy)

bar $=100 \mu \mathrm{m}, \mathrm{F}:$ sclerenchyma (sc), phloem (ph), bar $=100 \mu \mathrm{m}, \mathrm{G}:$ sclerenchyma $(\mathrm{sc})$, bar $=100 \mu \mathrm{m}, \mathrm{H}:$ prismatic crystal (p), bar $=20 \mu \mathrm{m}, \mathrm{I}:$ prismatic crystal $(p)$, bar $=20 \mu \mathrm{m}, \mathrm{J}:$ prismatic crystal (p), druz crystal (d), bar $=20 \mu \mathrm{m}, \mathrm{K}$ : cuticle (cu), epidermis (ep), stomate ( $)$ ), bar $=100 \mu \mathrm{m}$, L: epidermal hair (eh), bar $=100 \mu \mathrm{m}$, M: glandular hair $(\mathrm{gh})$, bar $=20 \mu \mathrm{m}$

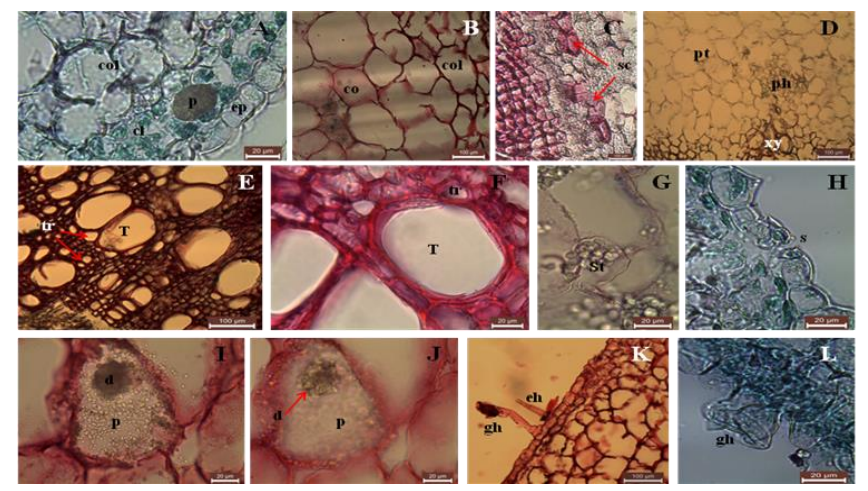

Figure 10. The anatomy of the stem cultivated $I_{2}$ (cross section). A: epidermis (ep), chlorenchyma (cl), prismatic crystal ( $p)$, collenchyma (col), bar $=20 \mu \mathrm{m}, \mathrm{B}$ : collenchyma (col), cortex (co), bar = $100 \mu \mathrm{m}, C:$ sclerenchyma (sc), bar = $100 \mu \mathrm{m}, \mathrm{D}:$ phloem (ph), xylem (xy), pith (pt), bar $=100 \mu \mathrm{m}$, E: trachea $(T)$, tracheid (tr), bar $=100 \mu \mathrm{m}, \mathrm{F}:$ trachea $(T)$, tracheid (tr), bar $=20 \mu \mathrm{m}, \mathrm{G}:$ starch (St), bar $=20 \mu \mathrm{m}, \mathrm{H}:$ stomate $(\mathrm{s})$, bar $=20 \mu \mathrm{m}$, I: prismatic crystal (p), druz crystal (d), bar $=20 \mu \mathrm{m}, \mathrm{J}$ : prismatic crystal (p), druz crystal (d), bar $=20 \mu \mathrm{m}, \mathrm{K}$ : epidermal hair (ep), glandular hair (gh), bar $=100 \mu \mathrm{m}$, L: glandular hair (gh), bar $=20 \mu \mathrm{m}$ 


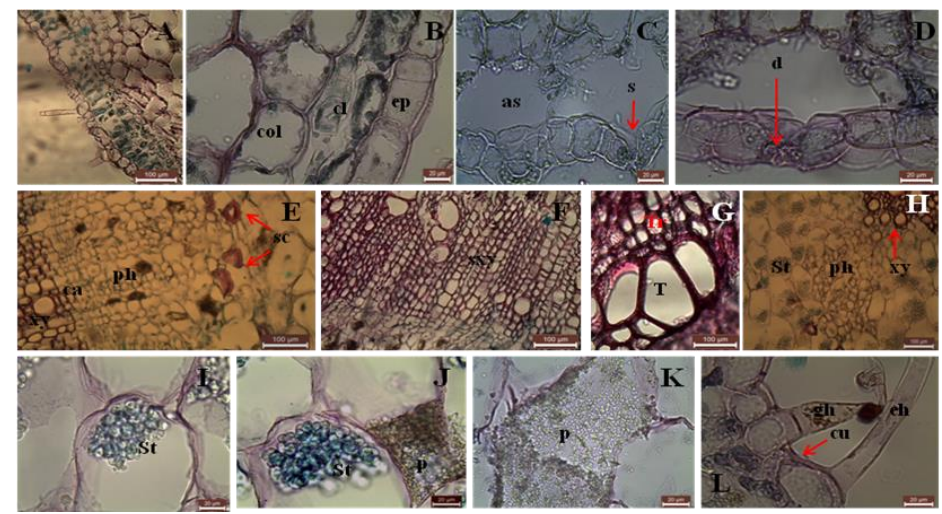

Figure 11. The anatomy of the stem cultivated $I_{3}$ (cross section). A: general shape of some tissues, bar $=100 \mu \mathrm{m}, \mathrm{B}$ : epidermis (ep), chlorenchyma (cl), collenchyma (col), bar $=20 \mu \mathrm{m}$, C: stomate (s), air space (as), bar $=20 \mu \mathrm{m}, \mathrm{D}:$ druz crystal (d), bar $=20 \mu \mathrm{m}$, E: sclerenchyma (sc), phloem (ph), cambium (ca), xylem (xy), bar $=100 \mu \mathrm{m}$, F: seconder xylem (xy), bar $=100 \mu \mathrm{m}, \mathrm{G}:$ trachea $(T)$, tracheid (tr), bar $=100 \mu \mathrm{m}, \mathrm{H}:$ phloem (ph), xylem (xy), starch $(S t)$, bar $=100 \mu m$, I: starch (St), bar $=20 \mu \mathrm{m}, \mathrm{J}: \operatorname{starch}(\mathrm{St})$, prismatic crystal $(p)$, bar $=20 \mu \mathrm{m}, \mathrm{K}$ : prismatic crystal (p), bar $=20 \mu \mathrm{m}, \mathrm{L}$ : epidermal hair (eh), glandular hair (gh), cuticle (cu), bar $=20 \mu \mathrm{m}$

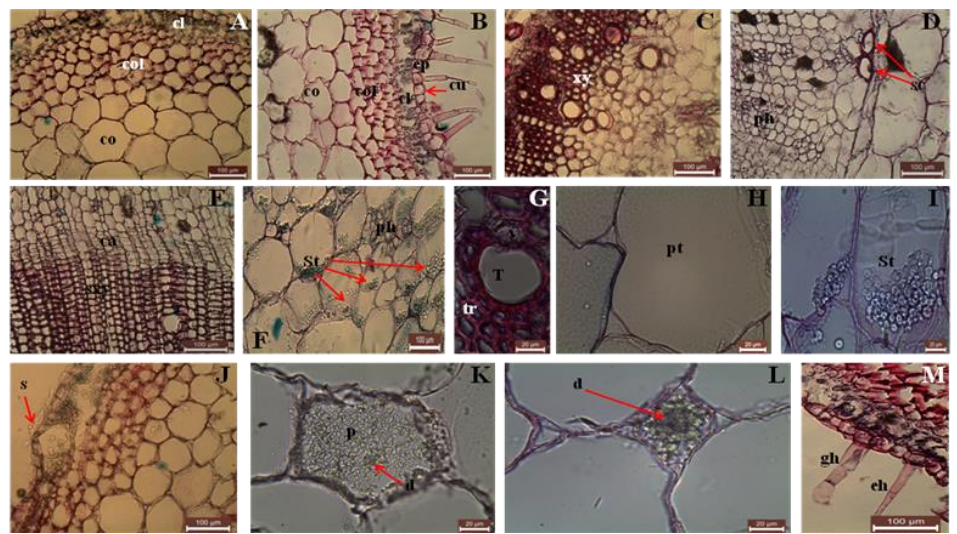

Figure 12. The anatomy of the stem cultivated $I_{4}$ (cross section). A: chlorenchyma (cl), collenchyma (col), cortex (co), bar $=100 \mu \mathrm{m}, \mathrm{B}$ : cuticle (cu), epidermis (ep), chlorenchyma

(cl), collenchyma (col), cortex (co), bar $=100 \mu \mathrm{m}, \mathrm{C}: x y l e m(x y)$, bar $=100 \mu \mathrm{m}, \mathrm{D}$ : sclerenchyma (sc), phloem (ph), bar $=100 \mu \mathrm{m}, \mathrm{E}$ : cambium (ca), seconder xylem (xy), bar $=100 \mu \mathrm{m}, \mathrm{F}$ : starch (St), phloem (ph), bar = $100 \mu \mathrm{m}$, G: trachea (T), tracheid (tr),

bar $=20 \mu \mathrm{m}, \mathrm{H}:$ pith (pt), bar $=20 \mu \mathrm{m}, \mathrm{I}: \operatorname{starch}(\mathrm{St})$, bar $=20 \mu \mathrm{m}, \mathrm{J}:$ stomate (s), bar $=100 \mu \mathrm{m}, \mathrm{K}$ : prismatic crystal (p), druz crystal (d), bar $=20 \mu \mathrm{m}, \mathrm{L}:$ druz crystal (d), bar $=20 \mu \mathrm{m}$, M: glandular hair (gh), epidermal hair (eh), bar $=100 \mu \mathrm{m}$

\section{Leaves}

The leaves under all the conditions were bifacial and amphistomatic. Mesophyll was formed by one-layered palisade parenchyma with large spaces between the cells and 4-5 layered spongy parenchyma with large spaces between the cells under $\mathrm{I}_{1}$ (Fig. 14). Palisade parenchyma was one-layered and spongy parenchyma was 2-3 layered under $\mathrm{I}_{2}$ (Fig. 15). Mesophyll was formed by 2-3 layered palisade parenchyma generally rarely arranged by small cells and 3-4 layered spongy parenchyma with large spaces between 
small cells under $\mathrm{I}_{3}$ (Fig. 16). One-layered palisade parenchyma formed by long cylindirical cells and 3-4 layered spongy parenchyma with large spaces between the cells in mesophyll under $\mathrm{I}_{4}$ were observed (Fig. 17). Druz crystals were observed among prismatic cyristals in mesophyll in some sections. Big vascular bundle was bicollateral. Small vascular bundles surrounded by bundle sheath were collateral and embedded in mesophyll. Epidermal and glandular hairs were observed under all the conditions. Glandular hairs were rarely seen under $\mathrm{I}_{4}$.
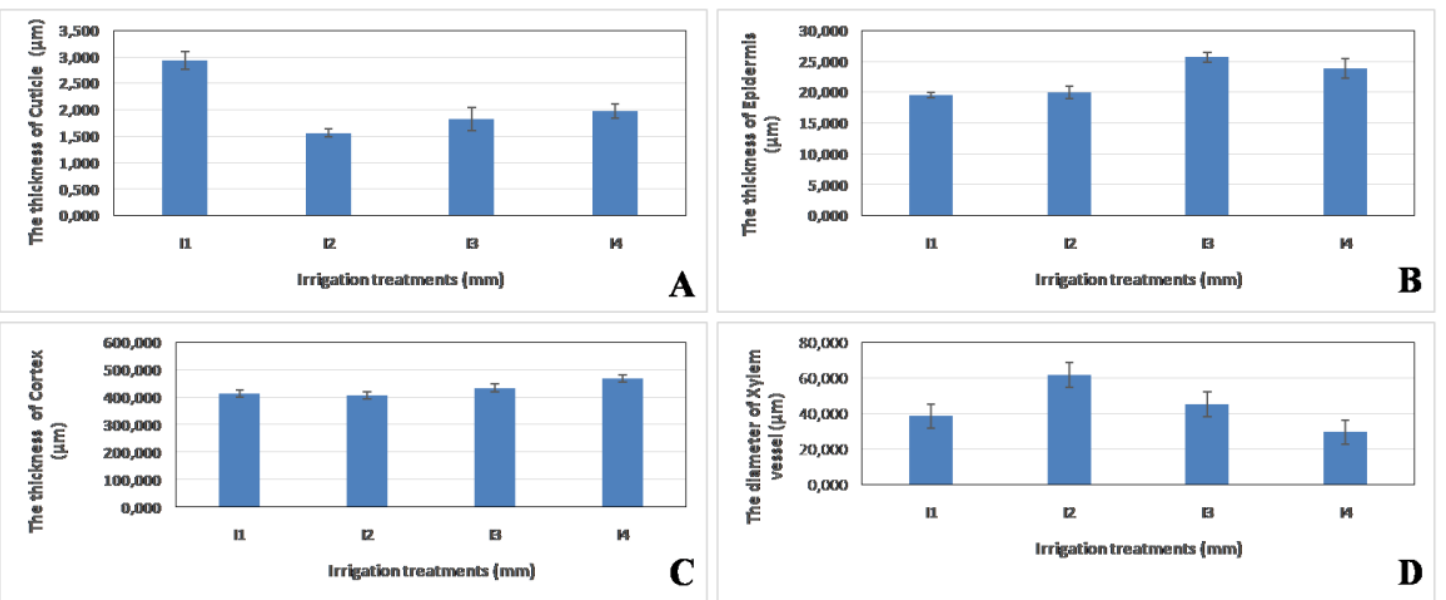

Figure 13. Measurements of some tissues in stems of Ceren cv. under different irrigation treatment conditions. A. The relationship between irrigation treatments and thickness of cuticle,

$B$. The relationship between irrigation treatments and thickness of epidermis, $C$. The relationship between irrigation treatments and thickness of cortex, $D$. The relationship between irrigation treatments and diameter of xylem vessel

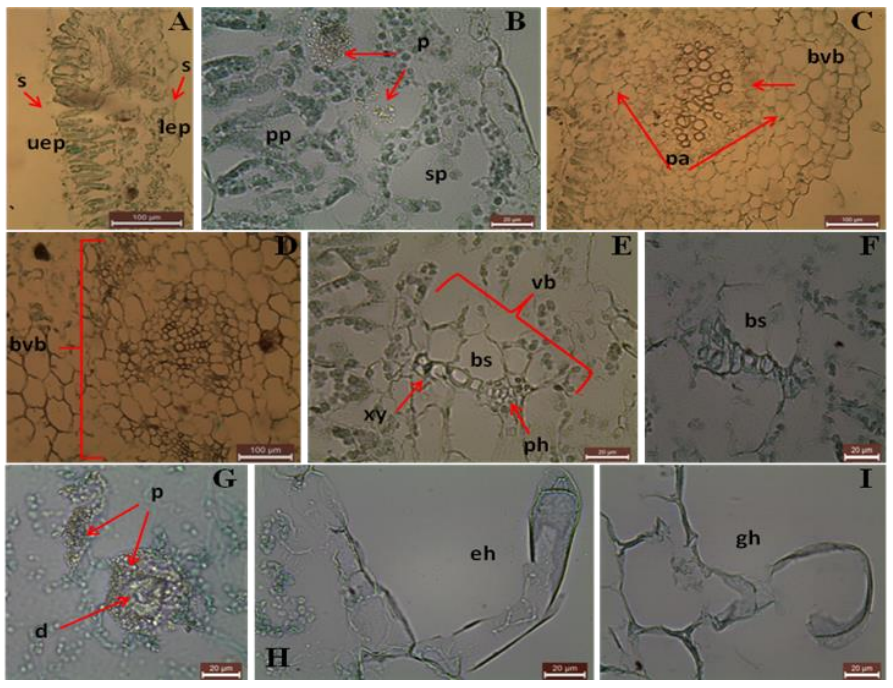

Figure 14. The anatomy of the leaf cultivated $I_{1}$ (cross section). A: upper epidermis (uep), lower epidermis (lep), stomate ( $($ ), bar $=100 \mu \mathrm{m}, \mathrm{B}:$ palisade parenchyma (pp), spongy parenchyma (sp), prismatic crystal (p), bar $=20 \mu \mathrm{m}, \mathrm{C}$ : big vascular bundle (bvb), parenchymatic tissue (pa), bar $=100 \mu \mathrm{m}$, D: big vascular bundle (bvb), bar $=100 \mu \mathrm{m}, \mathrm{E}$ : vascular bundle (vb), bundle sheath (bs), xylem (xy), phloem (ph), bar $=20 \mu \mathrm{m}, \mathrm{F}$ : bundle sheath (bs), bar $=20 \mu \mathrm{m}$, G: prismatic crystal (p), druz crystal (d), bar $=20 \mu \mathrm{m}, \mathrm{H}$ : epidermal hair (eh), bar $=20 \mu \mathrm{m}, \mathrm{I}$ : glandular hair $(\mathrm{gh})$, bar $=20 \mu \mathrm{m}$ 


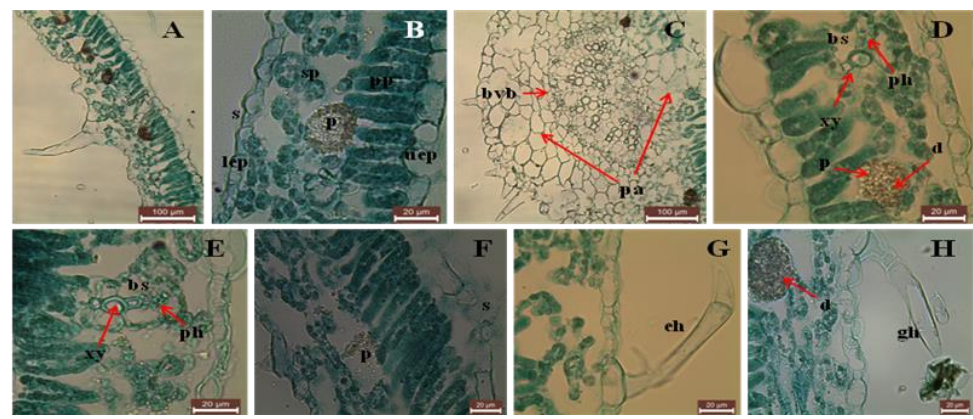

Figure 15. The anatomy of the leaf cultivated $I_{2}$ (cross section). A: general shape of leaf, bar $=100 \mu \mathrm{m}$, B: upper epidermis (uep), lower epidermis (lep), stomate (s), palisade parenchyma (pp), spongy parenchyma (sp), prismatic crystal (p), bar $=20 \mu \mathrm{m}, \mathrm{C}$ : big vascular

bundle (bvb), parenchymatic tissue (pa), bar $=100 \mu \mathrm{m}$, D: bundle sheath (bs), xylem (xy), phloem (ph), prismatic crystal (p), druz crystal (d), bar $=20 \mu \mathrm{m}$, E: bundle sheath (bs), xylem

(xy), phloem (ph), bar $=20 \mu \mathrm{m}, \mathrm{F}$ : stomate (s), prismatic crystal (p), bar $=20 \mu \mathrm{m}, \mathrm{G}$ : epidermal hair (eh), bar = $20 \mu \mathrm{m}, \mathrm{H}$ : glandular hair (gh), druz crystal (d), bar $=20 \mu \mathrm{m}$
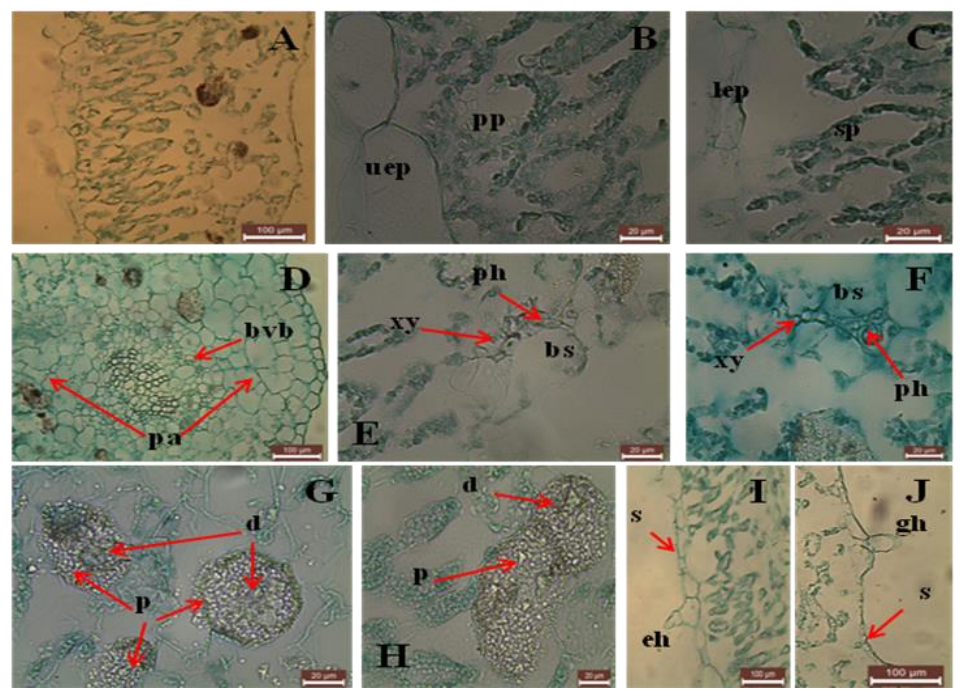

Figure 16. The anatomy of the leaf cultivated $I_{3}$ (cross section). A: general shape of leaf, bar $=100 \mu \mathrm{m}$, B: upper epidermis (uep), palisade parenchyma (pp), bar $=20 \mu \mathrm{m}, \mathrm{C}:$ lower epidermis (lep), spongy parenchyma (sp), bar $=20 \mu \mathrm{m}$, D: big vascular bundle (bvb), parenchymatic tissue (pa), bar $=100 \mu \mathrm{m}, \mathrm{E}$ : bundle sheath (bs), xylem (xy), phloem (ph), bar $=20 \mu \mathrm{m}, \mathrm{F}$ : bundle sheath (bs), xylem (xy), phloem (ph), bar $=20 \mu \mathrm{m}, \mathrm{G}$ : prismatic crystal

(p), druz crystal (d), bar $=20 \mu \mathrm{m}$, H: prismatic crystal (p), druz crystal (d), bar $=20 \mu \mathrm{m}, \mathrm{I}$ : stomate (s), epidermal hair (eh), bar $=100 \mu \mathrm{m}$, J: glandular hair (gh), stomate (s),

$$
\text { bar }=100 \mu \mathrm{m}
$$

According to the biometric measurements performed in some tissues of the leaves under four conditions; the thickness of cuticle decreased under $\mathrm{I}_{1}(p<0.05)$, but it did not change under $\mathrm{I}_{3}$ and $\mathrm{I}_{4}(p>0.05)$. The thickness of upper epidermis was affected clearly under $\mathrm{I}_{1}, \mathrm{I}_{3}$, and $\mathrm{I}_{4}(p<0.01 ; p<0.01 ; p<0.05$, respectively). The lower epidermis increased under $\mathrm{I}_{1}(p<0.01)$, but it did not change under $\mathrm{I}_{3}$ and $\mathrm{I}_{4}(p>0.05)$. The width of mesophyll and the length of big vascular bundle increased under $\mathrm{I}_{1}, \mathrm{I}_{3}$, and $\mathrm{I}_{4}(p<0.01 ; p<0.01 ; p<0.01$, respectively). The width of big vascular bundle 
increased under $\mathrm{I}_{1}$ and $\mathrm{I}_{4}$ ( $p<0.01 ; p<0.05$, respectively), but it decreased under $\mathrm{I}_{3}$ $(p<0.05)$. The thickness of bundle sheath wall did not change clearly under $\mathrm{I}_{1}$ and $\mathrm{I}_{3}$ $(p>0.05)$, but it increased under $\mathrm{I}_{4}(p<0.05)$. The diameter of xylem vessel narrowed under $\mathrm{I}_{3}$ and $\mathrm{I}_{4}(p<0.05 ; p<0.01$, respectively), but it did not change obviously under $\mathrm{I}_{1}(p>0.05)$. According to the results of the biometric measurements, the leaves under the other issues underwent anatomical changes statistically comparing to the ones under $\mathrm{I}_{2}$ and the $\mathrm{I}_{2}$ condition was determined as optimum issue (Fig. 18).
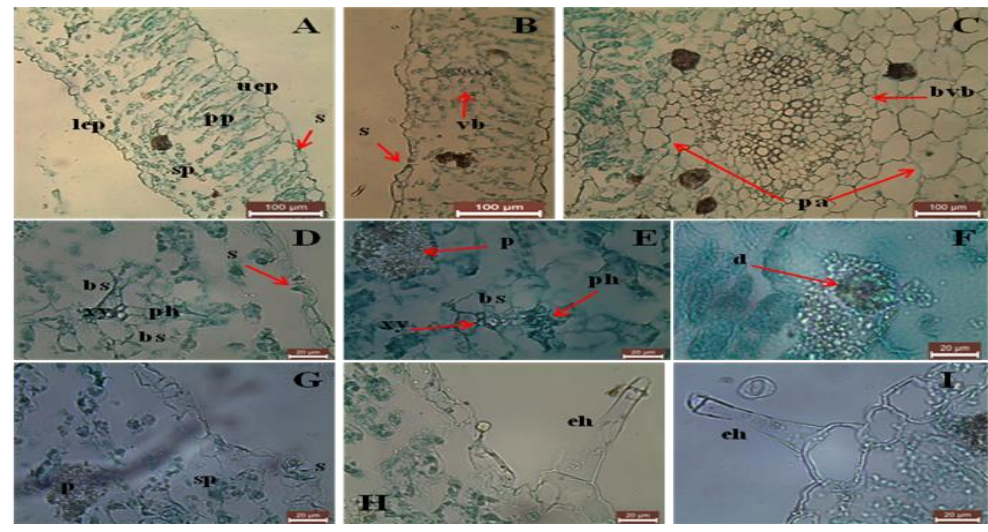

Figure 17. The anatomy of the leaf cultivated $I_{4}$ (cross section). A: upper epidermis (uep), lower epidermis (lep), stomate ( $s$ ), palisade parenchyma ( $p p)$, spongy parenchyma ( $\mathrm{sp}$ ),

bar $=100 \mu \mathrm{m}$, B: stomate (s), vascular bundle (vb), bar $=100 \mu \mathrm{m}, \mathrm{C}:$ big vascular bundle (bvb), parenchymatic tissue (pa), bar $=100 \mu \mathrm{m}, \mathrm{D}$ : bundle sheath (bs), xylem (xy), phloem (ph), stomate ( $(s)$, bar $=20 \mu \mathrm{m}$, E: bundle sheath (bs), xylem (xy), phloem (ph), prismatic crystal (p),

bar $=20 \mu \mathrm{m}, \mathrm{F}:$ druz crystal (d), bar $=20 \mu \mathrm{m}, \mathrm{G}:$ stomate (s), spongy parenchyma (sp), prismatic crystal (p), bar $=20 \mu \mathrm{m}, \mathrm{H}$ : epidermal hair (eh), bar $=20 \mu \mathrm{m}$, I: epidermal hair (eh),

$$
\text { bar }=20 \mu \mathrm{m}
$$

\section{Discussion}

According to the results the anatomical features in the roots, stems and leaves in the issues analyzed are similar to the general anatomical features of Solanaceae family and Lycopersicon esculentum Mill. mentioned in Metcalfe and Chalk (1950), Rost (1996), Tuylu et al. (2018) and Tuylu (2018a). Abnormal changes in the development of basic tissues were not observed in the roots, stems and leaves in all the issues studied $\mathrm{I}_{1-4}$. Structure and functions of all plant organs are affected by water stress (Sam et al., 2000). The tissues affected when the plant is applied by limited irrigation can be also affected by over-irrigation. The adaptation reactions of the tissues under over-irrigation or limited irrigation condition can be opposite or parallel to each other. In the study the $I_{1}$ issue was determined as over-irrigation. The comparison of the biometric measurements between the issues in the study and the results of the measurements of the tomato, Ceren cv. cultivated under hydroponic system and anatomically examined in Tuylu (2018a) contributed to determine $\mathrm{I}_{1}$ issue as overirrigation. The study mentioned was carried out in the same greenhouse, period and climate parameters. The stress- related anatomical changes were observed in the roots, stems and leaves of the plants cultivated under $\mathrm{I}_{3}$ and $\mathrm{I}_{4}$ issues determined as limited irrigation conditions comparing with the ones under $\mathrm{I}_{2}$ issue determined as optimum condition. 
When the results were evaluated for the root, the diameter of xylem vessels in the root in Ceren cv. narrowed in all the issues more than the one under optimum issue. It means that the diameter of xylem vessels anatomically reacted to water and drought stress conditions in the same way. The xylem vessels under $I_{1}$ condition in the study and the ones in Ceren cv. cultivated under hydrophonic culture in Tuylu (2018a) gave the same reactions. Similarly, Tuylu et al. (2018) figured out in the study on Malatya Kurucaova cv. that the xylem vessels in the root narrowed as a result of water stress under hydrophonic culture more than the ones under perlite condition well- irrigated. The xylem vessels in Malatya Kurucaova cv. and Ceren cv. gave reactions in parallel anatomically to stress resulting in over- irrigation.
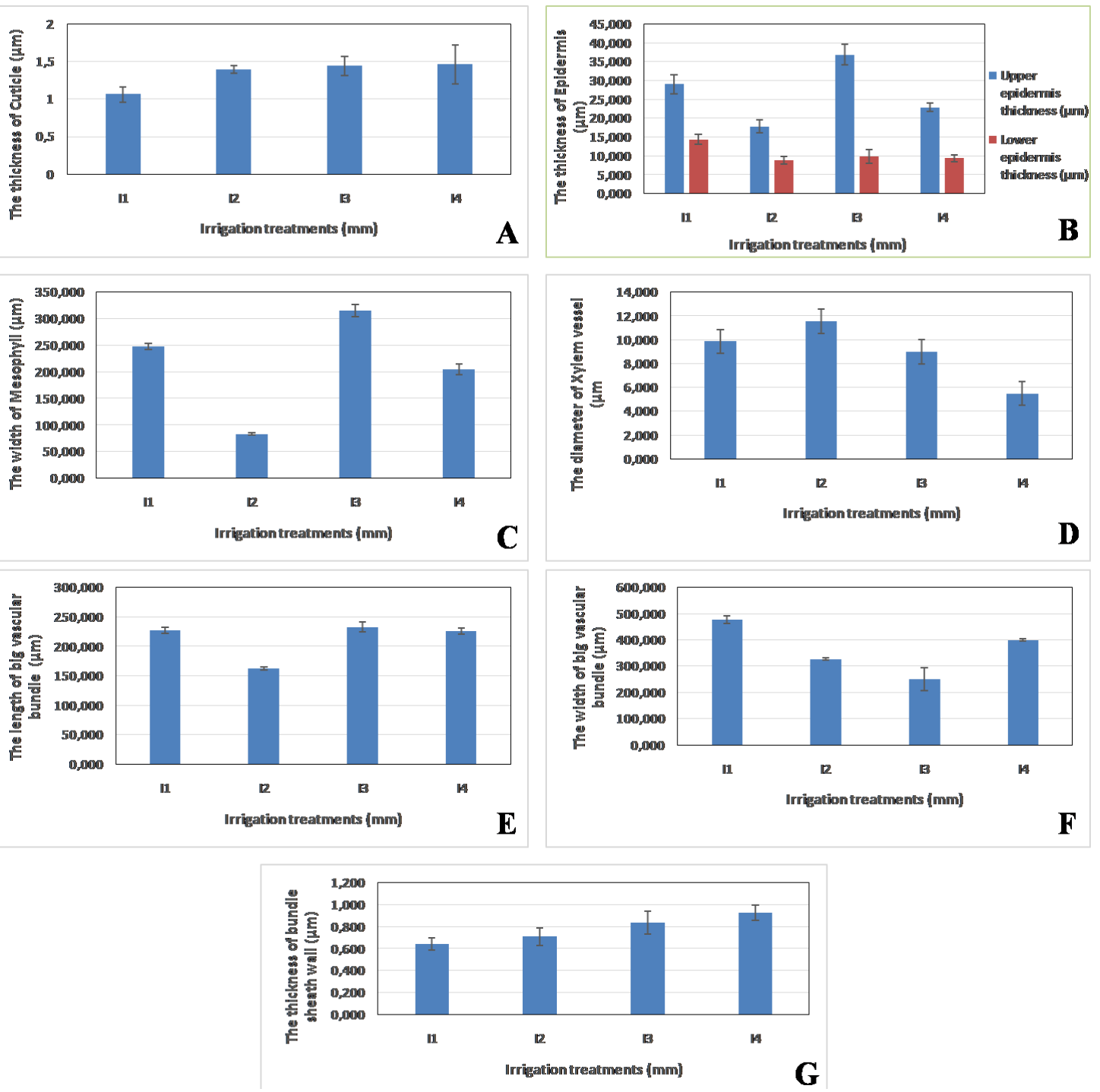

Figure 18. Measurements of some tissues in leaves of Ceren cv. under different irrigation treatment conditions. A. The relationship between irrigation treatments and thickness of cuticle,

$B$. The relationship between irrigation treatments and thickness of epidermis, $C$. The relationship between irrigation treatments and width of mesophyll, D. The relationship between irrigation treatments and diameter of xylem vessel, E. The relationship between irrigation treatments and length of big vascular bundle, $F$. The relationship between irrigation treatments and width of big vascular bundle, G. The relationship between irrigation treatments and thickness of bundle sheath wall 
When the results were evaluated for the stem, it was observed that cuticle and cortex thickened and the diameter of xylem vessel narrowed under $\mathrm{I}_{1}, \mathrm{I}_{3}$, and $\mathrm{I}_{4}$ conditions comparing with $\mathrm{I}_{2}$ condition. In the stem of Ceren cv. mentioned in Tuylu (2018a) the thickness of cuticle increased and the diameter of xylem vessel narrowed comparing with $\mathrm{I}_{2}$ in the study. In the stem of Malatya Kurucaova cv. in Tuylu et al. (2018) it was stated that cuticle and epidermis thickened while cortex and xylem vessel narrowed under hydrophonic condition. It was clear that the thickness of cuticle and the diameter of xylem vessel anatomically changed in parallel in Ceren cv. and Malatya Kurucaova cultivated under hydrophonic condition and under over- irrigation and limited irrigation conditions in the present study.

When the results were evaluated for the leaf, it was obvious that upper and lower epidermis thickened under $\mathrm{I}_{1}, \mathrm{I}_{3}$, and $\mathrm{I}_{4}$ conditions comparing to $\mathrm{I}_{2}$ condition. Sam et al. (2000) studied the effects of water deficit on epidermis of leaf at preflowering stage in Lycopersicon esculentum Mill. cv. INCA9 and stated that water stress have slight effects on the width and the length of epidermis cells. Thus, it is understood that the plant also shows epidermal change under water stress as it shows under water deficit. In addition, in the present study, the width of mesophyll increased, the diameter of xylem vessel narrowed and the length of big vascular bundle increased. While the width of big vascular bundle increased under $\mathrm{I}_{1}$ and $\mathrm{I}_{4}$, it decreased under $\mathrm{I}_{3}$. The thickness of bundle sheath wall increased as long as the amount of irrigation water reduced. Tuylu et al. (2018) introduced that midrib region widened and the width and the length of big vascular bundle increased in the leaf of Malatya Kurucaova cv. cultivated under hydrophonic condition as a result of water stress comparing to the ones under perlite condition. They stated that no clear change was observed in the other tissues measured. It was similar to the change observed in midrib region of the plant cultivated and exposed to over- irrigation under $\mathrm{I}_{1}$ in the present study. A similar change in big vascular bundle was observed under particularly $\mathrm{I}_{4}$ which was one of the limited irrigation issues. However; the fact that in the study the leaf under $\mathrm{I}_{1}$ also showed anatomical changes in the other tissues comparing to the one under $\mathrm{I}_{2}$ differed from Tuylu et al. (2018).

The fact that the thickness of upper epidermis and mesophyll increased and xylem narrowed in the leaf of Ceren cv. exposed to over- irrigation in Tuylu (2018a) was similar to the leaf under $I_{1}$ in the present study.

Tuylu (2018b) figured out that the thickness of cortex and the diameter of xylem vessel in the root, the diameter of xylem vessel in the stem and the thickness of cuticle, the thickness of upper epidermis, the number of stomate in the upper and the lower epidermis, the length and the width of bullate cell, the width of mesophyll, the diameter of xylem vessel, the distance of bundles, the thickness of midrib region, and the width of big vascular bundle in the leaf significantly changed under over- irrigation and limited irrigation in the study on the maize cultivar.

\section{Conclusion}

As a result, some tissues of Ceren cv. cultivated under perlite condition by applying different irrigation issues were anatomically examined and compared. When all the issues were compared according to the measurements performed in the root, stem and leaf, the tissues under $\mathrm{I}_{1}, \mathrm{I}_{3}$ and $\mathrm{I}_{4}$ conditions showed anatomical changes due to drought and water stress comparing to $\mathrm{I}_{2}$ condition. 
Thus, the anatomical features analyzed pointed out that $\mathrm{I}_{2}$ issue was optimum irrigation condition for the plant. It was the issue that $10 \%$ of irrigation solution was drained. The plants cultivated under over- irrigation $\left(\mathrm{I}_{1}\right)$ and limited irrigation $\left(\mathrm{I}_{3}, \mathrm{I}_{4}\right)$ did not have a clear anatomical anomaly comparing to the ones cultivated under $\mathrm{I}_{2}$. They underwent changes such as thickening or narrowing due to water and drought stress and they adapted to the conditions.

To determine the accurate irrigation strategy for the plant under irrigation applications some tissues of the root, stem and leaf can anatomically present if the plant was exposed to water stress or drought stress. In the study, it was figured out that the thickness of cortex under limited irrigation, and the diameter of xylem vessels under over- irrigation and limited irrigation in the root, the thickness of cuticle, and the diameter of xylem vessel under over- irrigation, and the thickness of cuticle, epidermis and cortex, and the diameter of xylem vessel under limited irrigation in the stem, the thickness of cuticle, the width of mesophyll, and upper and lower epidermis, the length and width of big vascular bundle under over- irrigation, and the thickness of upper epidermis, the width of mesophyll, the diameter of xylem vessel, the length and width of big vascular bundle, the thickness of bundle sheath wall under limited irrigation in the leaf significantly reacted anatomically. The optimum issue can be determined statistically in terms of importance levels by evaluating the measurements of these tissues.

According to the results of the study, it is suggested that the amount of drainage should be $10 \%$ in the irrigation applications in contrast to $30-35 \%$ drainage mentioned in Winsor and Shwarz (1990), Lieth (1996) and Öztekin et al. (2017). In other words, irrigation application should be performed by reducing $25 \%$ of irrigation water. It is suitable for the anatomical characteristics of the root, stem and leaf of tomato. In cultivation, not only saving up the cost of the nutrient solution in terms of its total cost but also supplying energy savings by reducing irrigation time will contribute considerably to the producer. In addition, researchers in the field should consider irrigation parameter to optimize the ecological condition in further studies.

Acknowledgements. This research did not receive any specific financially funding, but we thank to Harran University for equipments in greenhouse, and Ankara University for biology laboratories in Turkey for providing materials mentioned in the Materials and Methods to support the study.

Conflict of interests. The authors declare that there is no conflict of interests.

\section{REFERENCES}

[1] Anonymous (2015): Crop Production Statistics (Türkiye İstatistik Kurumu, Bitkisel Üretim İstatistikleri). $\quad-\quad$ Turkish Statistical Institute, Ankara. http://www.tuik.gov.tr/bitkiselapp/bitkisel.zul (accessed on 14.04.2016).

[2] Anonymous (2016): Şanlıurfa Climate Values (Şanlıurfa iklim değerleri). - Regional Directorate of Meteorology Data Base (Meteoroloji Bölge Müdürlüğü Veri Tabanı), Şanliurfa, Turkey. https://www.mgm.gov.tr/ (accessed on 19.03.2017).

[3] Deliboran, A., E., Gülle Sakin, E. D., Çoşkun, M. (2013): Evaluation of the some productivity characteristics of greenhouse soils at strict Karaali Şanlıurfa. - Soil-Water Journal 2(2): 1077-1084.

[4] Demirok, A., Tuylu, G. İ. (2017): Evaluation of planning and actual irrigation time scheduling for the maize (Zea mays L.) plant in Harran plain (Harran Ovası'nda Misir 
Bitkisi (Zea mays L.) için Planlanan ve Gerçekleşen Sulama Zamanı Programının Değerlendirilmesi). - Harran Journal of Agricultural and Food Science (Harran Tarım ve Gida Bilimleri Dergisi) 21(1): 84-90.

[5] Korkmaz, H., Durmaz, A. (2017): Responses of plants to abiotic stress factors (Bitkilerin Abiyotik Stres Faktörlerine Verdiği Cevaplar). - GUFBED 7(2): 192-207.

[6] Lieth, J. H. (1996): Irrigation Systems. - In: Reed, D. W. (ed.) Water, Media and Nutrition for Greenhouse Crops. Ball Publishing Inc., Chicago, IL.

[7] Metcalfe, C. R., Chalk, L. (1950): Anatomy of the Dicotyledons. Vol. II. - Clarendon Press, Oxford, pp. 965-978.

[8] Özkan, Ş. (2014): Soilless agricultural production, current and future situation of soilless agricultural products in 2012-2013 cultivated in the Mediterranean region of Turkey. A Study on "tomato and strawberry" (Topraksız Tarım Üretimi, 2012-2013 Y1llarında Türkiye'nin Akdeniz Bölgesi'nde Gelişmekte Olan “Topraksız” Tarım Ürünlerinin Bugünkü Durumu ve Gelecekle İlgili Tahminler, Domates ve Çilek Üretimi Üzerine Bir Araştırma). - Yüksek Lisans Tezi, Giresun Üniversitesi Sosyal Bilimler Enstitüsü, Giresun.

[9] Öztekin, G. B., Tüzel, Y., Tüzel, İ. H. (2017): Effect of silicium on salt stress under soil less tomato cultivation in greenhouse (Serada topraksız domates yetiştiriciliğinde silisyumun tuz stresine etkisi). - Journal of Academical Agriculture (Akademik Ziraat Dergisi), Special Issue (Özel Sayı) 6: 243-256.

[10] Rost, T. L. (1996): Tomato Anatomy. - Section of Plant Biology Division of Biological Sciences, University of California, Davis. http://wwwplb.ucdavis.edu/labs/rost/Tomato/tomhome.html (accessed on 17.10.2017).

[11] Sam, O., Jerez, E., Dell'Amico, J., Ruiz Sanchez, M. C. (2000): Water stress induced changes in anatomy of tomato leaf epidermis. - Biologia Plantarum 43(2): 275-277.

[12] Söylemez, S., Pakyürek, A. Y. (2017): Responses of rootstocks to nutrient induced high EC levels on yield and fruit quality of grafted tomato cultivars in greenhouse conditions. Applied Ecology and Environmental Research 15(3): 759-770.

[13] Tuylu, M. (2018a): Examination of anatomical features of tomato (Lycopersicon esculentum Mill.) varieties cultivated under hydroponic system. - Applied Ecology and Environmental Research 16(3): 3381-3391.

[14] Tuylu, G. İ. (2018b): Effect of ecological conditions created by over- irrigation and limited irrigation on the anatomy of corn. - Applied Ecology and Environmental Research 16(6): 7619-7634.

[15] Tuylu, M., Büyükkartal, H. N., Akgül, G., Kalyoncu, H. (2017): Comparing stem and leaf anatomy of Marrubium lutescens Boiss. and M. cephalanthum Boiss. \& Noë subsp. akdaghicum (Lamiaceae) (Marrubium lutescens Boiss. ve M. cephalanthum Boiss. \& Noë subsp. Akdaghicum (Lamiaceae)' un Gövde veYaprak Özelliklerinin Anatomik Olarak Karşılaştırılması). - Süleyman Demirel Üniversitesi Fen Bilimleri Enstitüsü Dergisi 21(1): 113-117.

[16] Tuylu, M., Tuylu, G. İ., Söylemez, S., Büyükkartal, H. N. (2018): Comparing some anatomical features of tomato (Lycopersicon esculentum Mill. cv. Kurucaova) cultivated under perlit and hydroponic culture (Perlit ve Su Kültürü Ortamlarında Yetiştirilen Domates (Lycopersicon esculentum Mill. cv. Kurucaova) Bitkisinin Bazı Anatomik Özelliklerinin Karşılaştırılması). - Süleyman Demirel Üniversitesi Fen Bilimleri Enstitüsü Dergisi 22(2): 1104-1109.

[17] Winsor, G. W., Schwarz, M. (1990): Soilless Culture for Horticulture Crop Production. FAO Plant Production and Protection, Paper 101, Rome.

[18] Yanmaz, R., Duman, İ., Yaralı, F., Demir, K., Sarıkamış, G., Sarı, N., Balkaya, A., Kaymak, H. Ç., Akan, S., Özalp, R. (2015): Changes in vegetable production and new research (Sebze Üretiminde Değişimler ve Yeni Arayışlar). - Turkey Agriculture Engineering VIII. Technique Congress (Türkiye Ziraat Mühendisliği VIII. Teknik Kongresi), Ankara, Turkey, 12-16 January, Proceeding Book-1 (Bildiriler Kitabi-1), pp. 579-605. 